\title{
Evidence of a normal mean telomere fragment length in patients with Ullrich-Turner syndrome
}

\author{
Marie Kveiborg ${ }^{1,4}$, Claus Højbjerg Gravholt*,2,4 and Moustapha Kassem ${ }^{3}$ \\ ${ }^{1}$ Danish Centre of Molecular Gerontology, Århus University Hospital, DK-8000 A rhus C, Denmark; ${ }^{2}$ Department \\ of Endocrinology $M$ and Medical Research Laboratories, Arhus University Hospital, DK-8000 Århus C, Denmark; \\ ${ }^{3}$ Department of Endocrinology and Metabolism, Arhus University Hospital, DK-8000 Arhus C, Denmark
}

\begin{abstract}
Clinical and epidemiological studies suggest that premature ageing and increased morbidity and mortality is present in Ullrich-Turner syndrome. We studied telomere restriction fragment length (TRFL) in 30 women with Ullrich-Turner syndrome and 30 age-matched control women. All Turner women had the 45,X karyotype verified by karyotyping. We found no difference in the mean TRFL in the young age group (TS: $7011 \pm 521$ vs C: $7285 \pm 917 \mathrm{bp}, P=0.3$ ), or in the older age group (TS: $7357 \pm 573$ vs $C: 7221 \pm 621 \mathrm{bp}, P=0.6$ ). In conclusion, our data suggest that Ullrich-Turner syndrome is not associated with excessive telomere loss, at least when studied in peripheral blood leucocytes, and thus quite different from other premature ageing syndromes. European Journal of Human Genetics (2001) 9, 877-879.
\end{abstract}

Keywords: Ullrich-Turner syndrome; ageing; telomere restriction fragment length; mortality; morbidity

The essential features of Ullrich-Turner syndrome are growth retardation with reduced final height, gonadal insufficiency (female sex hormone deficiency) and infertility. Patients with Ullrich-Turner syndrome exhibit increased morbidity throughout their entire lifespan. ${ }^{1}$ Thus, several studies have documented that patients with Ullrich-Turner syndrome have increased frequency of cardiovascular diseases, ${ }^{1,2}$ compromised immune response and a high prevalence of thyroid diseases and thyroid antibodies, ${ }^{3}$ early sensineuronal hearing loss, ${ }^{4}$ abnormal endocrine functions, impaired glucose tolerance (being present in $50 \%$ of adult patients), and type 2 diabetes $^{2,5}$ (diabetes is viewed by some as a segmental progeroid syndrome ${ }^{6}$ ), a low bone mineral content $^{7-9}$ and a high frequency of osteoporosis and fractures. $^{1,10}$ Finally, the life expectancy is decreased in females with Ullrich-Turner syndrome. ${ }^{11-13}$ The available data suggest that Ullrich-Turner syndrome is associated with

*Correspondence: CH Gravholt, Department of Endocrinology M, Århus Kommunehospital, Århus University Hospital, DK-8000 Århus C,

Denmark. Tel: +45894920 71; Fax: +45894920 10;

E-mail: ch.gravholt@dadlnet.dk

${ }^{4}$ These authors contributed equally to this work

Received 9 April 2001; revised 8 August 2001; accepted 17 August 2001 premature ageing and increased early morbidity and mortality.

Telomeres are nucleoprotein complexes at the ends of chromosomes consisting of tandem arrays of TTAGGG nucleotide repeats of up to $10-15$ kilobase-pairs $(\mathrm{kb})$. They are essential for chromosome stability and for preventing degradation and abnormal chromosomal recombinations. ${ }^{14}$ During cell division, there is a continuous process of telomere shortening because of the nature of the DNA replication process. ${ }^{15}$ It has been suggested that shortened telomeres signal a growth check-point that triggers irreversible cell cycle-arrest manifested as cellular senescence. ${ }^{15,16}$ Excessive telomere shortening has been observed in fibroblasts from patients with premature ageing syndromes such as Werner's syndrome and Hutchinson-Gilford progeria ${ }^{17,18}$ and in peripheral blood leukocytes (PBL) in patients with ataxia telangiectasia ${ }^{19}$ and Down's syndrome. ${ }^{20}$ Furthermore, estrogen activates telomerase, a cellular reverse transcriptase that catalyses synthesis and extension of telomeric DNA, activity both directly and indirectly by upregulation of hTERT (human telomerase reverse transcription subunit), ${ }^{21}$ thus indicating a causative role of estrogen in regulating telomerase in tissues expressing the enzyme. Recently, it has also been shown that accelerated telomere shortening is seen in 
the inactive $X$ chromosome in female humans, ${ }^{22}$ the significance of which is not clear at the moment.

In the present study we tested the hypothesis that UllrichTurner syndrome is associated with excessive telomere shortening. We determined telomere fragment length employing DNA obtained from a large sample of patients with Ullrich-Turner syndrome $(45, \mathrm{X})$ and age-matched controls.

Thirty women with Ullrich-Turner syndrome and 30 age matched control women were studied (Table 1). All women with Ullrich-Turner syndrome were not menstruating and most were taking female hormone replacement therapy. All had the 45 ,X karyotype verified by karyotyping. DNA was extracted from PBL using a standard method. ${ }^{23}$ Mean telomere restriction fragment length (TRFL) was measured by Southern blotting analysis as previously described. ${ }^{24}$ As TRFL decreases with age, the participants were divided into two groups. A young group with participants between 20-30 years, and an older group with participants between 40-50 years (Table 1). Data were examined by Students two-tailed unpaired $t$-test. Pearson correlation was used to examine the relation between TRFL and duration of oestrogen therapy in women with Ullrich-Turner syndrome. Results are expressed as the mean \pm standard deviation (SD). Significance levels under 5\% were considered significant. All statistical calculations were done with SPSS for Windows version 10.0 (SPSS Inc., Chicago, Illinois, USA) on a Pentium PC.

We found no difference in the mean TRFL in the young age group (TS: $7011 \pm 521$ vs C: $7285 \pm 917 \mathrm{bp}, P=0.3$ ) (Figure 1). Similarly no difference in TRFL was seen in the older age group (TS: $7357 \pm 573$ vs C: $7221 \pm 621 \mathrm{bp}, P=0.6$ ). There was no age-related changes in the mean TRFL between young and old age groups in patients with Ullrich-Turner syndrome or in controls. We found no correlation between duration of oestrogen treatment in the group of women with UllrichTurner syndrome and the mean TRFL $(r=0.107, P=0.6)$. This was also true after correction for chronological age ( $r=0.095, P=0.6)$.

Our data suggest that Ullrich-Turner syndrome is not associated with excessive telomere loss and thus quite different from other premature ageing syndromes. Our inability to detect differences in the mean TRFL between patients with TS and controls was not due to the sample size as our study has a $90 \%$ power to detect a $10 \%$ difference in the mean TRFL between patients with TS and age-matched controls.

Table 1 Age, number and mean telomere restriction fragment length (TRFL) in young and old individuals

\begin{tabular}{lllll}
\hline & & Age/years & Number & TRFL/bp \\
\hline \multirow{2}{*}{ Young } & Ullrich-Turner syndrome & $24.8 \pm 3.0$ & 15 & $7011 \pm 521$ \\
& Controls & $23.7 \pm 1.9$ & 15 & $7285 \pm 917$ \\
Old & Ullrich-Turner syndrome & $42.9 \pm 6.5$ & 15 & $7357 \pm 573$ \\
& Controls & $47.1 \pm 3.8$ & 15 & $7221 \pm 621$ \\
\hline
\end{tabular}

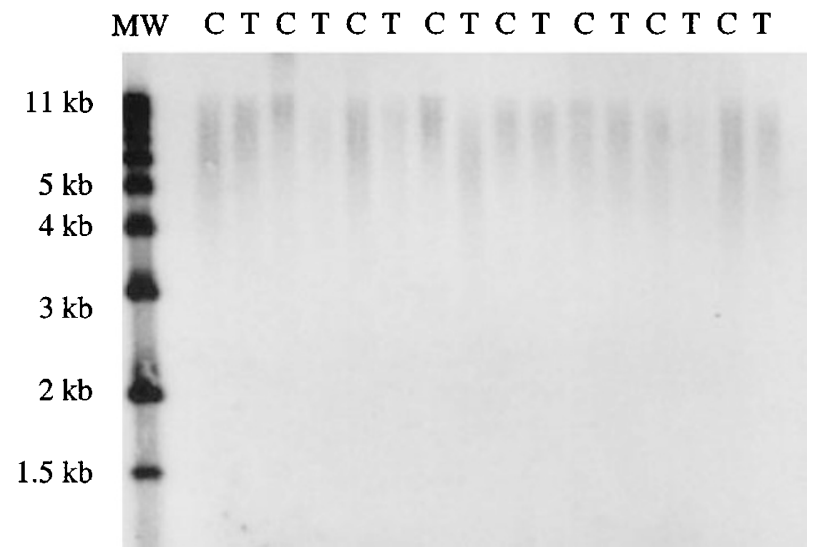

Figure 1 Representative Southern blot analysis of individual mean telomere restriction fragment length for Turner $(T) v s$ control (C) samples.

While epidemiological and clinical studies suggest that Ullrich-Turner syndrome is associated with excessive morbidity and mortality, the mean TRFL was not a sensitive marker for this phenotype. However, our study has some limitations. First, we studied an unselected group of patients with Ullrich-Turner syndrome which may be heterogenous with respect to their risk factors and disease complication. A group of patients with Ullrich-Turner syndrome with evidence of morbidity may reveal abnormalities in the mean TRFL. Second, we measured the mean TRFL. As different chromosomes may have different rates of telomere shortening, a study of telomere length of individual chromosomes may be more informative. ${ }^{22}$ Third, we measured mean TRFL in PBL which may have a high turnover and renewal from hematopoietic stem cells in the bone marrow. Studies of other cell types from the organs affected by excessive morbidity eg, endothelial cells or osteoblasts, may reveal abnormalities that were not detected in the PBL. However, recent data suggest that although the absolute telomere restriction fragment length may be different in different tissues from the same individual, there is a rather tight correlation between the TRFL in different healthy tissues and this suggests that the genetic determination of the regulation of TRFL is tissue-independent. ${ }^{25}$

Alternatively, our findings may suggest that other factors apart from intrinsic cellular defects are responsible for the observed increased morbidity and mortality in patients with TS. Endocrine deficiency (eg, estrogen deficiency) which is almost always present in Ullrich-Turner syndrome or other hormonal deficiencies, like androgen ${ }^{26,27}$ or growth hormone insufficiencies ${ }^{28}$ may lead to metabolic abnormalities and increased morbidity. Also, other yet unknown factors or genes located on the 'missing' $\mathrm{X}$ chromosomes might contribute to the Ullrich-Turner syndrome phenotype. Studying the relative contributions of these factors remains to be determined. 


\section{References}

1 Gravholt CH, Juul S, Naeraa RW, Hansen J: Morbidity in Turner syndrome. J Clin Epidemiol 1998; 51: 147-158.

2 Gravholt CH, Naeraa RW, Nyholm B et al: Glucose metabolism, lipid metabolism, and cardiovascular risk factors in adult Turner syndrome: the impact of sex hormone replacement. Diabetes Care 1998; 21: 1062-1070.

3 Larizza D, Martinetti Bianchi M et al: Autoimmunity, HLA, Gm and $\mathrm{Km}$ polymorphisms in Turner's syndrome. Autoimmunity 1989; 4: $69-78$.

4 Hultcrantz M, Sylven L: Turner's syndrome and hearing disorders in women aged 16-34. Hear Res 1997; 103: 69-74.

5 Nielsen J, Johansen K, Yde H: The frequency of diabetes mellitus in patients with Turner's syndrome and pure gonadal dysgenesis. Blood glucose, plasma insulin and growth hormone level during an oral glucose tolerance test. Acta Endocrinol Copenh 1969; 62: $251-269$.

6 Martin GM, Oshima J: Lessons from human progeroid syndromes. Nature 2000; 408: $263-266$.

7 Sylven L, Hagenfeldt K, Ringertz H: Bone mineral density in middle-aged women with Turner's syndrome. Eur J Endocrinol 1995; 132: $47-52$.

8 Garden AS, Diver MJ, Fraser WD: Undiagnosed morbidity in adult women with Turner's syndrome. Clin Endocrinol Oxf 1996; 45: $589-593$.

9 Landin-Wilhelmsen K, Bryman I, Windh M, Wilhelmsen L: Osteoporosis and fractures in Turner syndrome-importance of growth promoting and oestrogen therapy. Clin Endocrinol (Oxf) 1999; 51: 497-502.

10 Emans SJ, Grace E, Hoffer FA, Gundberg C, Ravnikar V, Woods ER: Estrogen deficiency in adolescents and young adults: impact on bone mineral content and effects of estrogen replacement therapy. Obstet Gynecol 1990; 76: $585-592$.

11 Price WH, Clayton JF, Collyer S, De Mey R, Wilson J: Mortality ratios, life expectancy, and causes of death in patients with Turner's syndrome. J Epidemiol Community Health 1986; 40: 97 102.

12 Naeraa RW, Gravholt CH, Hansen J, Nielsen J, Juul S: Mortality in Turner syndrome. In Turner syndrome in a life span perspective: Research and clinical aspects. Albertsson-Wikland K, Ranke MB, Eds. Amsterdam, Elsevier, 1995, p. 323 - 323.

13 Swerdlow AJ, Hermon C, Jacobs PA et al: Mortality and cancer incidence in persons with numerical sex chromosome abnormalities: a cohort study. Ann Hum Genet 2001; 65: 177-188.

14 Blackburn EH: Telomeres: no end in sight. Cell 1994; 77: $621-$ 623.
15 Levy MZ, Allsopp RC, Futcher AB, Greider CW, Harley CB: Telomere end-replication problem and cell aging. $J$ Mol Biol 1992; 225: $951-960$

16 Harley CB: Telomere loss: mitotic clock or genetic time bomb? Mutat Res 1991; 256: 271-282.

17 Allsopp RC, Vaziri H, Patterson C et al: Telomere length predicts replicative capacity of human fibroblasts. Proc Natl Acad Sci USA 1992; 89: $10114-10118$

18 Kruk PA, Rampino NJ, Bohr VA: DNA damage and repair in telomeres: relation to aging. Proc Natl Acad Sci USA 1995; 92: $258-262$.

19 Metcalfe JA, Parkhill J, Campbell L et al: Accelerated telomere shortening in ataxia telangiectasia. Nat Genet 1996; 13: 350353.

20 Vaziri H, Schachter F, Uchida I et al: Loss of telomeric DNA during aging of normal and trisomy 21 human lymphocytes. Am J Hum Genet 1993; 52: $661-667$.

21 Kyo S, Takakura M, Kanaya T et al: Estrogen activates telomerase. Cancer Res 1999; 59: 5917-5921.

22 Surralles J, Hande MP, Marcos R, Lansdorp PM: Accelerated telomere shortening in the human inactive $\mathrm{X}$ chromosome. Am J Hum Genet 1999; 65: $1617-1622$.

23 Sambrook J, Fritsch EF, Maniatis T: Molecular cloning. A laboratory manual. Cold Spring Harbor, Cold Spring Harbor Laboratory Press, 1989

24 Kveiborg M, Kassem M, Langdahl BL, Eriksen EF, Clark BFC, Rattan SIS: Telomere shortening during aging of human osteoblasts in vitro and leukocytes in vivo: lack of excessive telomere loss in osteoporotic patients. Mech Aging Dev 1999; 106: $261-271$.

25 Friedrich U, Griese E, Schwab M, Fritz P, Thon K, Klotz U: Telomere length in different tissues of elderly patients. Mech Ageing Dev 2000; 119: 89-99.

26 Apter D, Lenko HL, Perheentupa J, Soderholm A, Vihko R: Subnormal pubertal increases of serum androgens in Turner's syndrome. Horm Res 1982; 16: 164-173.

27 Gravholt CH, Svenstrup B, Bennett P, Christiansen JS: Low androgen levels in adult Turner syndrome: influence of female sex hormones and growth hormone status. Clin Endocrinol Oxf 1999; 50: 791-800.

28 Gravholt $\mathrm{CH}$, Frystyk J, Flyvbjerg A, Orskov H, Christiansen JS: Reduced free IGF-I and increased IGFBP-3 proteolysis in Turner syndrome: modulation by female sex steroids. Am J Physiol 2001; 280: E308-E314. 